\title{
Culture in Glocalization Process: A Study of Indonesian Newspapers
}

\author{
Fikry Zahria Emeraldien \\ Universitas Pembangunan Nasional "Veteran" Jawa Timur \\ E-mail: fikryzahria.ilkom@upnjatim.ac.id
}

\begin{abstract}
The present study examines the construction of global to the local content in Indonesian newspapers after New Order Era, Indonesia former President Suharto's regime that was ended in 1998. In the so-called Reform Era, Indonesia entered a new phase of democratization which brings democracy towards newspapers and other media. Compared to the New Order Era, Indonesian newspapers currently have more variation in term of content, especially for entertainment. After employing a content analysis, Indonesian newspapers, which are Kompas and Jawa Pos, through their cross-cultural news in the entertainment section, are proved become more open to the other cultures. They have transformed from dominantly homogeneous -in 2004- to hybrid -in 2014- within glocalization, a perspective that can see micro-sociological phenomenon. This notion proves that glocalization does proceed, rather than keep constant, depending on the different cultural systems and structures, as well as the degree of local perception of glocalization.
\end{abstract}

Keywords: Glocalization, globalization, pop culture, Indonesia Reform Era, crossculture

Abstrak - Penelitian ini mengkaji konstruksi global untuk konten lokal di surat kabar Indonesia setelah Era Orde Baru, rezim mantan Presiden Indonesia Suharto yang berakhir pada tahun 1998. Di era yang disebut Era Reformasi tersebut, Indonesia memasuki fase baru demokratisasi yang membawa demokrasi terhadap surat kabar dan media massa lainnya. Dibandingkan dengan Era Orde Baru, surat kabar Indonesia di Era Reformasi memiliki lebih banyak variasi dalam hal konten, terutama untuk konten hiburan. Setelah melakukan analisis isi pada berita-berita lintas budaya di rubrik hiburan surat kabar Indonesia, yaitu Kompas dan Jawa Pos, dapat dibuktikan bahwa surat kabar di Indonesia berproses menjadi lebih terbuka untuk budaya lain. Mereka telah berubah dari dominan homogen -pada tahun 2004- ke hibrid pada tahun 2014- dalam glokalisasi, yaitu perspektif yang dapat melihat fenomena dari kaca mata mikro-sosiologis. Penelitian ini membuktikan bahwa glokalisasi berproses, bukannya konstan, tergantung sistem dan struktur budaya serta tingkat persepsi pada masing-masing lokal di dalam glokalisasi.

Kata kunci: Glocalization, globalization, pop culture, Indonesia Reform Era, crossculture

\section{Introduction}

Globalization is often seen from the macroscopic point of view. It is mostly studied in the economic, communication, and political areas (Dyczewski, 2012). In the economic area, for example, globalization process laid on the free flow of the capital, commodities, and services as well as technology in the integration of markets. It forms corporations with global dimensions such as IMF and the World Bank. In the political area, globalization can be seen in the forming of common institutions for maintaining security like the UN and NATO. However, globalization is not merely a 
homogenization. In the opposite, it enhances cultural identity (Wang, 2007).

A clear example can be seen when Gillette Sensor Excel razor entered the Japan market. As a global product, Gillette launched many advertisements that were meshed with the local culture. Whether it is headline wording or visualization product, the strategies are changing the US style to the Japanese taste. This negotiation process is perceived as the glocalization (Michael, 2003). The same process also happens when the Indonesian media report a cross-cultural news story. Its negotiation process has known as glocalization.

This study examines cross-cultural phenomenon by using the glocalization as a lens for analyzing it because glocalization perspective can see that micro-sociological phenomenon. Utilizing this angle, this study sees a global phenomenon as a cultural homogeneity, heterogeneity, or hybridity (Robertson, 1995). The phenomenon studied is cross-cultural news in the entertainment section of Kompas and Jawa Pos, representative newspapers in Indonesia. Because glocalization is a process, this study observes the transformation of cross-cultural news in the Reform Era, which occurred after the New Order Era. In the Reform Era, freedom of press undergoes a significant improvement (Kakiailatu, 2007) along with economic growth (Brown, 2011), and new foreign political policies (He, 2008).

\section{Literature Review}

\section{Glocalization}

Glocalization is not internationalization or modernization (Robertson, 1995), but a concept that is usually used to draw an anti-ethnocentric. Glocalization can be seen in Taiwan when the young audience of Japanese TV dramas might love Titanic movie and singer Mariah Carey, but they are more addicted to the romance like Japanese TV dramas Tokyo Love Story and Lobe Generation as well as singers Faye Wong and Utada Hikaru. This phenomenon explained (Iwabuchi, 2001), is a process when cultural proximity meets resonance among young audiences of Japanese TV dramas in Taiwan.

Studying glocalization in the sports area, Giulianotti \& Robertson (2012) studied how both homogenization and heterogenization plays in the most basic ways. Based on their analysis, sports have undergone global diffusion, which points toward homogenization. Meanwhile, when most societies interpret, organize, and play these sports in distinctive ways, it demonstrates heterogenization. Nonetheless, Robertson (1995) do not see homogenization and heterogenization opposite to each other, even though they indeed can and do collide in concrete situations. Homogenization and heterogenization are interrelated -while global and local interpenetrate- but we still can see the tendency of the consequence of glocalization process, whether it is likely to be homogenous or heterogeneous in term of culture.

Cultural homogeneity probably has the same interpretation of globalization, the first view, by Achterberg, Heilbron, Houtman, and Aupers (Achterberg, Heilbron, Houtman, and Aupers, 2011), by which the cultural exchange between countries expands and that countries around the globe increasingly enjoy foreign cultural goods besides their domestic production, may lead to the one dominant culture. There is international domination by the United States that results in a more homogeneous and uniform global culture.

The interpretation of cultural heterogeneity asserts that increasing cultural 
exchange leads to increasing cultural diversity or multiculturalization. Various cultural flows, originating from anywhere around the globe, are held to increasingly coexist within one cultural space. The cultural forms coexist rather than blend.

Moreover, hybridity is an inevitable consequence when we talk about glocalization construction. Two or various aspects of different cultures blend into a new cultural hybridity (Robertson, 1995), while cultural forms are actively adapted according to local circumstances (Achterberg, et al., 2011). It predicts that localized versions of successful global brands or institutions will emerge, enabling local appropriations that constitute authentic expressions of local, national or regional cultures (Kjeldgaard \& Askegaard, 2011). In the global context, cultural hybridity can be seen on the global micromarketing methods of Sony Walkman aforementioned. While in the Indonesian entertainment context, there is a musician named Jogja HipHop foundation that unites hip-hop music with the Javanese song lyrics.

Process of glocalization in the cultural thing varies depending on the context or "different cultural systems and structures, as well as the degree of local perception of glocalization" (Ju, 2010, p. 46). She continued (cf. Mosco, 1996) "differing cultural and industrial systems and visions for change in the local arena affect the degree, types, and rate of globalization present in the local culture and industry" (Ju, 2010, p. 46).

The transaction of cultures can be possible in anywhere because of cultural proximity (Straubhaar, 1991). Cited from Lin (2006), this term refers to "the local preference for certain imported cultural products and their forms" (p. 6). This cultural proximity enables audiences to prefer a far-foreign television program due to some similarities. For example, language, religion, dress, music, non-verbal codes, humor, story pacing, and ethnic types (Lin, 2006, p. 6). Cited from Rachmah Ida (in Heryanto, 2013), Iwabuchi concluded that:

"the cultural flows from 'the non-Western semi-centre' and the rise of the economic power of transnational media corporations in a global space, have shown alternative patterns of transnationalization of media and popular culture from those non-Western countries to their regional markets under the banner of locality, that is 'a non-Western mode of indigenized modernity for culturally and/or geographically contiguous nations'" (p. 99).

\section{Pop Culture}

According to many studies in social-cultural science, there is a good relationship between pop culture and glocalization. The more recent time, the more pop cultures are glocalized. Cultural processes in glocalization are diverse, depends on the context or different cultural systems and structures. It also depends on the degree of local perception of glocalization too $(\mathrm{Ju}, 2010)$.

Glocalization process in Indonesia can be different from the glocalization process in South Korea if they apprehend glocalization differently. Each local customs, context, value and meaning systems, and tastes also distinguish the process. Indonesia has four major ideological forces (Islam, liberalism, Javanism, and Marxism) that have fundamentally dictate the parameters of Indonesian nation-state building as well as frame the debates in the production and consumption of pop culture (Heryanto, 2013).

The cross-cultures consumed by Indonesian people can be an originally imported from the outside (in this context, remaining as homogenous), it also can be 
blended with Indonesian local cultures (hybrid), or it coexists with local cultures. For example, Lion Dance Performance on Chinese New Year which has been blended with the Chinese-Indonesian people in every Chinese New Year celebration. The Indonesia aborigine are also familiar with this so-called barongsai since it has been routinely performed in shopping mall for commemorating Chinese New Year.

Meteor Garden, an Asia-widespread Taiwanese drama, was also successfully imported and gained massive popularity in Indonesia. The Meteor Garden series brought big influences to Indonesian. Almost everyone in Indonesia knows Dao Ming $\mathrm{Si}$ and Shan Cai, the main roles in the series. When the series were broadcasted in Indonesia, the haircut and fashion of Dao Ming Shi became a new trending style. Until now, the word Dao Ming Si refers to men with long hair and wearing low collar shirts. The more recent trend shows the greater level and scope of acceptance of the foreign and non-Western media products and pop cultures in local television markets.

\section{Indonesian Media in Reform Era}

Reform Era occurred after New Order Era. Unlike in New Order Era, national press in Reform Era is "free". Based on the Law on press No. 40, 1999, press provides the public's right to know and obtain information, enforces basic democratic values, promoting the establishment of the rule of law and human rights, and respecting diversity, developing a general opinion based on informed, accurate, and true, to supervise, criticism, corrections, and suggestions on issues related to the public interest, fighting for justice and truth.

Importing cross-cultural content such as entertainment was exploding in the early of Reform Era. Television stations are competing to get the audience's attention by showing more mini-series (sinetron), foreign drama, and music show. Unlike the TV show program that is easily changed according to rating, entertainment section at the newspaper is continuously maintained. "Hiburan" and "Show \& Selebriti" (entertainment section's title of Kompas and Jawa Pos), for example, still become a well-maintained section.

\section{Research Method}

Because glocalization is a process, this study examines two important periods of Indonesia Reform Era, which are early and the latest, using the object cross-cultural news in the entertainment section of Kompas and Jawa Pos newspaper named Hiburan and Show \& Selebriti with the research question:

RQ: “How do Indonesian newspapers construct glocalization through its crosscultural news on the entertainment section in the early (2004) and recent (2014) Indonesia Reform Era, whether they are more likely to present cultural homogeneity, hybridity, or heterogeneity?"

While the hypotheses are:

- H1: Cross-cultural news in the entertainment section of Indonesian newspapers has transformed from 2004 to 2014.

- H2: Cross-cultural news in the entertainment section of Indonesian newspapers has been kept constant from 2004 to 2014.

Studies with glocalization theoretical framework have been done in various methodology, both the quantitative or qualitative techniques of research have been 
used for the study. Every method has its own characteristic and strength to support particular study and this study chooses quantitatively content analysis as the method.

\section{Content Analysis}

A content analysis is employed to generate a conclusion from textual materials and has been defined as a statistical technique for obtaining descriptive data. According to Holsti (1969), content analysis is any technique for making inferences and systematically identifying a specified characteristic of the message. The method is popular with mass media researchers since it is able to provide an efficient way to investigate the content of the media. In content analysis, researches examine the unit of analysis, which is a recording unit. It can be words, themes, sentences, or phrases (Abbot, 2011).

General basic steps in doing content analysis use a classic but popular determination by Wimmer \& Dominick (1983), as followed: formulate the research question and hypotheses, define the population, select an appropriate sample from population, select and define a unit of analysis, construct the categories of content to be analyzed, train coders and conduct a pilot study, code the content according to established definition, analyze the collected data, and draw conclusion and search for indication.

\section{Sample}

The universe of this study is cross-cultural news on the entertainment section of Jawa Pos (Show \& Selebriti) and Kompas (Hiburan), in 2004 and 2014. The sample is 138 editions of Show \& Selebriti in June to October 2004 and January to May 2014; 42 editions of Hiburan in June to October 2014 and January to May 2014. Furthermore, units of this study are every headline's photo in the news that has been determined as a sample and every headline's theme in the news that has been determined as a sample.

\section{Research Instruments}

According to Wimmer \& Dominick (1983), the important thing in content analysis is category system. It is used to classify media content. As the coding sheet is the tool to load the categories, the prior instrument of this research is the coding sheet. Instead of SPSS, a free software environment for statistical computing and graphics, " $R$ software" would be employed to get the precise result of the research.

\section{Development of Categories}

These categories may have some similar interpretations with Achterberg, Heilbron, Houtman, and Aupers (2011) in their "three views on cultural globalization".

The first view is cultural imperialism or American hegemonizing, comes from the "expanding transnational cultural exchange that has been profitable above all to the West, and especially to the United States, which has established a firm hegemonic position". The modern culture base, mostly represented by "the West, the United States, in particular, is increasingly held to command more peripheral (non-American, non-Western) cultures. However, globalization consequence is not actually an American hegemonizing (only), as we can see how the resonance of Korean Pop (KPop) nowadays with its "Korean wave". The spread of Korean culture has globally recognized, while Asian countries are the biggest consumer and the United States has 
decent K-Pop fandoms. Thus, term cultural homogeneity is preferred to note as the first category.

The second interpretation is cultural hybridity, referred to as a consequence of glocalization, which is a dynamic in which global cultural are actively adapted according to local circumstances. Achterberg, Heilbron, Houtman, and Aupers (2011) explained that this underscores the increasing importance of local cultural identity in counterbalancing growing global pressures (e.g., Gillette in Maynard, 2003). The third and last one is cultural heterogeneity, perceived as a cultural diversity due to the increasing transnational cultural exchange. This exchange leads to multiculturalization, that is, increasing cultural diversity an s aforementioned in the previous section.

\section{Operational Definition of Categories}

Three indicators are generated by utilizing and modifying categorization from some globalization studies, they are "people", "event", and "source". For instance, people can be grouped as homogenous when the photo and article shows or focuses on one nationality/race of the people only. The event is categorized as a hybrid when there are collaborative cultures in there, for example, Indonesian Idol and Indonesia Got Talent, the collaboration of Idol though/culture and Indonesian culture-people. The source can be grouped as heterogeneous when a photo or article involves multisources from various countries, such as a statement of SM Entertainment member Korean idol agency- and music chart of American billboard altogether written in one article.

\section{Results and Discussions}

Before doing the real research, a pilot study has been conducted first. Intercoder reliability of the pilot study is high, it is $89.15 \%$ for photos and $79.99 \%$ for articles. Due to knowing the reliability more precisely, a calculation set of intercoder reliability towards the real data or sample has been done too. The result remains reliable, which is $75.59 \%$ for indicator people, $84.04 \%$ for indicator event, and $78.94 \%$ for indicator source. Answering the research question that is stated in the previous section, this proves an existence of significant transformation in the entertainment section of Indonesian newspapers in an interesting way, which the tested hypotheses are explained as follow:

\section{Test of Hypotheses}

This study shows that the cross-cultural news in the entertainment section of Indonesian newspapers has different tendencies in presenting their content. Indonesian newspapers in 2004 were more likely to present cultural homogeneity message $(65.6 \%)$ as the top option, while the hybrid content was a half of the homogeneous (28\%). As the last option, heterogeneous came in 5.4\% of reports in 2004 . The rest was unidentified. On the other hand, the content distribution was more equitable in 2014. This time, cultural hybridity was most presented $(47.6 \%)$ in the crosscultural news in the entertainment section. A homogeneous report in 2014 was less dominant than in 2004, coming up with $40.2 \%$. Cultural heterogeneity was two-fold increasing in 2014, with $11.7 \%$.

Table 1. Cross-cultural news in Indonesian newspapers' entertainment section

\begin{tabular}{llllll}
\hline Category & 2004 & $\%$ & Category & 2014 & $\%$ \\
\hline
\end{tabular}




\begin{tabular}{lcclll}
\hline & $(\mathrm{N})$ & & & $(\mathrm{N})$ & \\
\hline Homogenous & 354 & 65.6 & Hybrid & 257 & $\begin{array}{l}47 . \\
6\end{array}$ \\
Hybrid & 151 & 28 & Homogeneous & 217 & $\begin{array}{l}40 . \\
2\end{array}$ \\
Heterogeneous & 29 & 5.4 & Heterogeneous & 63 & $\begin{array}{l}11 . \\
7\end{array}$ \\
$\begin{array}{l}\text { Other } \\
\text { (unidentified) }\end{array}$ & 6 & 1 & $\begin{array}{l}\text { Other } \\
\text { (unidentified) }\end{array}$ & 3 & 0.5 \\
\hline
\end{tabular}

The research question was then elaborated into two hypotheses to see whether the Indonesian newspapers transform their content $(\mathrm{H} 1)$ or not $(\mathrm{H} 2)$. Though the hypotheses only test a transformation of the trends in 2004 and 2014, the direction of these trends -whether it is homogeneous, hybrid, or heterogeneous- is explained too, due to providing more clarity and detail, rather than the simple result. After examining the data, the result emerges as below:

\section{Test of Hypothesis 1}

H1: Cross-cultural news in the entertainment section of Indonesian newspapers has been transformed from 2004 to 2014.

Hypothesis 1 is fully accepted. There is significant transformation of the crosscultural news in the entertainment section of Indonesian newspapers from 2004 to 2014 $\left(X^{2}=73.9748, \mathrm{df}=3, \mathrm{p}<0.05\right)$. It indicates that the notion of glocalization as a process supported by Robertson (1995), Maynard (2003) Cho (2009), Giulianotti (2012), and Ju (2010) is proved.

As we can see from table 1, the transformation is not led to the homogeneity or heterogeneity. Because, instead of increasing, cultural homogeneity content is decreasing from 2004 to 2014. In 2004, cultural homogeneity content presented is $65.6 \%$, while in 2014, cultural homogeneity presented is "only" $40.2 \%$. Besides, the transformation of cross-cultural news in the entertainment section of Indonesian newspapers from 2004 to 2014 is not led to the heterogeneity. Even though the number of cultural heterogeneity content from 2004 to 2014 is increasing (from 5.4\% to 11.7\%), but it is still far from dominant. In conclusion, it is true that the transformation leads to the hybridity, as the result shows that the trend comes from dominantly homogeneous in $2004(65.6 \%)$ changed to the dominantly hybrid (47.6\%). This result proves an interpretation that the more recent days, the more open Indonesia in terms of pop culture (see Heryanto Ariel; Hanam David; Ida Rachmah; Coutas Penelope; Jurriens Edwin, in Heryanto, 2013).

\section{Test of Hypothesis 2}

H2: Cross-cultural news in the entertainment section of Indonesian newspapers has been kept constant from 2004 to 2014.

Hypothesis 2 is fully rejected. This result indicates that the stagnancy of the globalization process found by Achterberg, Heilbron, Houtman, and Aupers (2011) does not apply here. Instead of constant, there is significant transformation of the cross-cultural news in the entertainment section of Indonesian newspapers from 2004 
to $2014\left(\mathrm{X}^{2}=73.9748, \mathrm{df}=3, \mathrm{p}>0.05\right)$.

This result is interesting as some globalization studies claimed that globalization is all about imperialism, Westernization (Lukens-Bull, 2000), or Americanization, which is identified with homogenization. In my perception, these perspectives did not seem to consider about the process or change, which in other words, instead of anticipating transformation within glocalization, those believed that the global and local nexus always flows in the homogenous direction. However, those perspectives are not proven in this thesis, as we can see from the result that even though cultural homogeneity was often reported and became dominant in 2004, the portion is decreasing from $65.6 \%$ (in 2004) to $40.2 \%$ (in 2014).

Due to see the trend of pop cultures in 2004 and 2014, this research also examines the trend tendency between these two years. A comparison test using chisquare has been done as well to know whether or not there is a significant change in both trends.

After coding the data, it results that the top three topics chosen by Indonesian newspapers in 2004 were a film (35\%), music (31\%), and infotainment (28\%). Meanwhile in 2014, music was ranked as the first choice (46\%), followed by film (29\%), and infotainment $(15 \%)$ with $\mathrm{X}^{2}=6.99, \mathrm{df}=4$, and $\mathrm{p}>0.05$. This result indicates that there is a different trend happening in 2004 and 2014. However, the trend transformation is not significant, since the p-value is more than 0.05 . While the film was the most chosen pop culture topic by Indonesian newspapers in 2004 , it was music the most reported topic in 2014.

Table 2. Pop cultures as the topic in Indonesian newspapers

\begin{tabular}{lccccc}
\hline \multicolumn{2}{c}{2004} & \multicolumn{5}{c}{2014} \\
\hline \multicolumn{1}{c}{ Category } & $N$ & $\%$ & Category & $N$ & $\%$ \\
\hline Film & 31 & 35 & Music & 41 & 46 \\
Music & 28 & 31 & Film & 26 & 29 \\
Infotainmen & 25 & 28 & Infotainment & 14 & 15 \\
$\mathrm{t}$ & & & & & \\
Drama & 3 & 3 & Drama & 3 & 3 \\
Other & 3 & 3 & Other & 6 & 7 \\
\hline
\end{tabular}

\section{Glocalization Equals to Hybridization?}

If Carl P. Watts ever questioned, "Is globalization another name for US imperialism?" (2011), then this study answers that "no". This research suggests that U.S. culture as well as media hegemony may exists in many Asian and numerous developing nations (see U.S. media hegemony in Hannerz, 1997), but local media industrial performance appears to be more active in exchanging media content and pop cultural commodities among media entities within regions (Ju, 2010, p. 15). For example, in the early 2000s, Indonesian television actively imported Korean (remains until now), Japanese, and Taiwanese TV youth dramas such as Meteor Garden, Winter Sonata, and Tokyo Love Story. The dramas had a significant number of fans in Indonesia, even Indonesian people have copied and absorbed some values to their life, 
at the moment (see the phenomenon in Rachmah Ida in Heryanto, 2013).

According to aforementioned notions, indeed glocalization is a process, that depending on the "different cultural systems and structures, as well as the degree of local perception of glocalization" (Ju, 2010, p. 46). This study totally agrees to the interdependence of the local and the global (Robertson, 1992), it also believes that the interdependence can be led to the several directions, whether to the homogeneity, hybridity, or heterogeneity.

However, this study acknowledges that glocalization process actually is leading to the hybrid direction. This statement is underpinned by many glocalization studies in the recent time which also argued the same thing. For example, Ju stated that Korean pop culture and the Korean value are more hybrid and localized as they have permeated to the local levels $(\mathrm{Ju}, 2010)$. She notes that evidence of glocalization in Korean Wave is seen in both content formation and industrial convention. Other examples are studied about Gillette hybrid advertising in Japan market (Maynard, 2003).

The same increasing hybridity pattern within glocalization currently happens in Indonesia. The process in Indonesia can be seen in the newspapers' entertainment section which has concerned to report cross-cultural news since the New Order Era came to an end. The news unveils the glocalization construction of Indonesian newspapers through their entertainment section, particularly the cross-cultural news. The cross-cultural news has brought the global content of popular cultures to its local platform, that formed a glocalization process. This evident strengthens Robertson' emphasize of cultural hybridity that cannot be ignored when we talk about glocalization construction, whereby the global and local interpenetrate and are blended rather than coexisted (Robertson, 1995).

When global and local culture interpenetrates within glocalization construction, adjustment among cultures is definitely inevitable. In Indonesian newspapers context, for example, the adjustment can be seen when the newspapers' entertainment section bring hybrid people, event, and source to their cross-cultural news. Indonesian newspapers filter out which global is appropriate to local culture, and the newspapers also choose, in which perspective the glocal can be presented to the local culture. Four major ideological forces in Indonesia by Heryanto, 2013, (Javanism, Islam, liberalism, and Marxism) become a parameter in consuming the other culture cultures. Photos in the Show \& Selebriti and Kompas never show an actress wearing too revealing clothes. If by any chance, the vulgar things must be reported, Indonesian newspapers tend to see it as impolite. For example, when Miley Cyrus was booming and doing a concert, she did a sensual choreographer by implying couple doing sexual intercourse and wore weed motived-revealed costume. Instead of her music or concert event, Indonesian newspapers chose to report the controversy of what Cyrus doing in that concert.

Back to the Gillette ad. example, the adjustment of the global to the local culture happens when Gillette entered Japan market. The worldwide Gillette brand, which is considered as global, was making an advertisement with the Japan taste (considered as the local), from the layout, wording, and the other visual things (see Maynard, 2003). There is such belief that a company can actually be global in a partial way and successful global brands will emerge in localized versions, enabling local 
appropriations that constitute authentic expressions of local, national or regional cultures (Kjeldgaard \& Askegaard, 2006).

If we see the origin of adjustment, Gillette ad, Korean wave phenomenon, and Sony Walkman, are actually an example of the glocalization that comes from outside to inside-perspective. Younghan Cho calls the perspective as glocalization from above, when, he examined, Transnational corporations e.g. MLB and ESPN attempt to cater to the nationalist affects of Korean MLB fans by using nationalism as the key marketing strategy (Cho, 2009). While this study portrays the glocalization phenomenon from inside to outside, or below, whereby the entertainment section in Indonesian newspapers reconstructs their understandings of the local taste as a choice to absorb the other cultures. However, these above and below are actually "only" a perspective. Same as global-local in the glocalization, the existence of both above and below cannot be removed partially, because when the culture from outside adjusts the local culture, local culture is absorbing the other culture at the same time.

\section{Heterogeneity and Homogeneity within Glocalization}

This study has emphasized that local and global interpenetrate in the glocalization. They are blended in a certain way, but the nexus of them can be also led to the homogeneous and heterogeneous, as what Robertson said that the local and the global certainly can and do collide in concrete situations. This study proves that heterogeneity is increasing from 2004 to 2014. Cultural diversity or multiculturalization is increasing, as the more heterogeneous "people" is increasing. It is plausible because Indonesia is more open to the other culture nowadays, many events involving diverse people are reported in Indonesian newspapers. Crane (2002), also emphasized that various cultural flows, originating from anywhere around the globe, are held to increasingly coexist side by side within one and the same cultural space.

Furthermore, homogeneity has been decreasing time by time. The increasing of hybrid events such as Indonesian Idol, X-Factor, etc, can be the reason. The decreasing of homogeneity within glocalization is also happening in East Asia countries. Ju explained that East Asia had been considered by the outside world as a single cultural bloc (Ju, 2010). They sharing common cultural sentiments and homogeneous popular culture primarily because of the geographical proximity of these countries. However, this overgeneralization failed to take a wide range of regional cultural differences. In many cases, East Asian media industries consist of different operating systems in terms of their broadcasting infrastructures and capabilities. In Indian journalism, glocalization remains the decreasing of homogeneity, since the local media is absorbing the global but rejuvenating the local at the same time. Ju stated that event though journalism practices integration of new information technologies and increased professional training of journalism students have become globalized, the news story or content continues to be highly localized.

\section{Musics, Entertainment, and Political Democratization in Indonesia}

Music appears as the only pop culture that is consistently reported in the hybrid news of Indonesian newspapers' entertainment section (see table 3). Therefore, I argue that musical events are more broadly accepted in Indonesia recently. It comes to the hybrid format when the Idol thought (considered as the global) has blended with Indonesian (considered as local) culture, industry, spectators, and participants. Indonesian Idol, X-Factor, and Indonesian Got Talents come as the most happening 
Idol-musical-event which confirms Fox" notion that "With the resounding success of the 'Idol' format in such culturally disparate countries, it would appear that we are seeing the emergence of a very particular and, importantly, transnational configuration of capital, mass media and popular culture" (Fox, 2006, p. 433).

Table 3. Pop Cultures Reported in the Cross Cultural News

\begin{tabular}{ccccc}
\hline Categories & Homogeneous & Hybrid & Heterogeneous & Other \\
\hline Music & 59 & 96 & 13 & 0 \\
Film & 148 & 28 & 8 & 2 \\
Infotainment & 119 & 20 & 7 & 4 \\
Other & 28 & 7 & 1 & 0 \\
\hline
\end{tabular}

This result asserts that music event, particularly; or entertainment, generally; cannot be ruled out by Indonesian newspapers, because it marks democratization in Indonesia. Indonesia had prior era so-called the Dutch colonization, Japanese colonization, Independence Day era, and Old Order, and New Order, which were forcing certain other culture and arguably did not welcome entertainment things. It can be proved in the newspapers from these eras, whereby newspaper used to be a propaganda tool to praise the Japanese government in the Japanese colonial era and a communication sabotage by government in the Independence Day era. At that time, freedom of press was handcuffed and newspapers totally did not have concern toward entertainment.

When newspapers were trying hard to fight for their freedom, democratioan was also struggled through musics. Iwan Fals and Slank have been become the icon of musicians who were very brave in criticizing government or elites. Iwan False often be blocked or banned in the Old Order Era because of his strong criticism in his song (lihat.co.id, 2013), but he was still braved to reveal his complaints and disappointment toward economic, political, and social condition in Indonesia. When democracy and freedom of speech have been guaranteed by government in the Reform Era, Indonesian newspapers and musicians work mutually, mantaining the freedom of speech and democracy they have been fought for. Entertainment content and musics in Indonesia are developed.

Therefore, entertainment must be maintained in the Indonesian newspapers. The portion might be less than the political issues, but the existence of entertainment shall not be abandoned, because it is the part of Indonesian democracy and freedom of speech. However, as the entertainment things have been developed very vast and "freely" in Indonesia nowadays, sometimes the quality is questionable while the good influence towards publics are doubted. Thus, this is the newspapers duty to maintain the "good" entertainment in their content. If the entertainment event has bad influence to the public, newspapers can ignore it or criticize it like what Kompas has done in criticizing boyband trend -that is perceived does not educate Indonesian people and doe not have good influence to Indonesian public- in a satire article. Kompas also warned the public whenever the entertainment product is "good" but need to be awared of. For example, when The Raid 2 Berandal (Indonesian action movie) came out 
as the world phenomena, Kompas noted that this movie is fantastic but very brutal and sadistic through its Hiburan section.

This study also implies that entertainment, especially music, is not only a primary supporting factor in constructing hybridization, but it also a marker of the political democracy in Indonesia. Furthermore, political democracy in Indonesia actually does follow glocalization.

\section{Conclusions and Recommendations}

Glocalization in Indonesia has been in process. The cross-cultural news in the entertainment section of Indonesian newspapers has been transformed in the recent decades. If the cross-cultural news of Indonesian newspapers' entertainment section in 2004 are more likely to be homogeneous in term of content, they become lesser homogeneous in 2014. On the contrary, hybridity which was has significantly increased. This study suggests that glocalization can be identified as hybridization, whereby the direction of glocalization consequence -which is uncertain sometimes- is led to the hybridity. Homogeneity may exist in the glocalization, but the glocalization will never lead to the homogeneity while glocalization is not equal to the homogenization.

Furthermore, this study recommends another categorization based on the origin of the global-local flow, which could be West and non-West. But if it is too broad, the categorization could be also countries or regions, depends on the topic of the study. Each of category should be explained very detail to the coders to avoid multiinterpretation and to keep the intercoder reliability high.

\section{References}

'Achterberg, P., Heilbron, J., Houtman, D., \& Aupers, S. (2011). A cultural globalization of popular music? American, Dutch, French, and German popular music charts (1965 to 2006). American behavioral scientist, 55(5), 589-608.

Abbott, B. B. (2011). Research design and methods: A process approach.

Brown, J. (2011). Foreign policy analysis. Cent. Indep. Stud., 5, 1-15.

Carl P. Watts. (2011). Is globalization another name for US imperialism?. Politics Review Online.,(20), 3.

Cho Younghan (2009). The glocalization of U.S. sports in South Korea. Sociology of Sport Journal, 26, 320-334.

Crane, D. (2002). Culture and Globalization: Theoretical Models and Emerging Trends. In D. Crane, N. Kamashima and K. Kawasaki (Eds.), Global Culture (pp. 1-28). London: Routledge.

Dyczweski, L. (2012). Culture in globalization process. Global Media Jurnal - Polish Edition, 1(9), 1-24.

Fox, R. (2006). Afterword. Asian Journal of Communication, 16 (4), 432-438.

Giulianotti, R. \& Robertson, R. (2012). Glocalization and sport in Asia: diverse perspectives and future possibilities. Sociology of Sport Journal. 29, 433-454.

Hannerz, U. (1997). Scenarios for peripheral cultures. In A. D. King (ed.) Culture, globalization and the world-system: Contemporary conditions for the representation of 
identity (pp.107-128). Minneapolis, MN: University of Minnesota Press.

He, K. (2008). Indonesia's foreign policy after Soeharto: international pressure, democratization, and policy change. International Relations of the Asia-Pacific,8(1), 47-72.

Heryanto, A. (2013). PoPular Culture for a New SoutheaSt aSiaN StudieS?.The Historical Construction of Southeast Asian Studies: Korea and Beyond, 226.

Holsti, O. R. (1969). Content analysis for the social sciences and humanities. Reading. MA: Addison-Wesley (content analysis).

Iwabuchi, K. (2001). Uses of Japanese popular culture: Trans/nationalism and postcolonial desire for'Asia'. Emergences: Journal for the Study of media \& Composite cultures, 11(2), 199-222.

Ju, H. (2010). Glocalization of the Korean Popular Culture in East Asia: Theorizing the Korean Wave (Doctoral dissertation, University of Oklahoma).

Kakiailatu, T. (2007). Media in Indonesia: Forum for political change and critical assessment. Asia Pacific Viewpoint, 48(1), 60-71.

Kjeldgaard, D. and S. Askegaard. (2006). The Glocalization of Youth Culture: The Global Youth Segment as Structures of Common Difference. Journal of Consumer Research 33: 231-247.

Lin, Ying-Chia. (2006). Culture, Technology, Market, and Transnational Circulation of Cultural Products: The Glocalization of EA Digital Games in Taiwan. (Doctoral dissertation, University of Washington).

Lukens-Bull, R. A. (2000). Teaching morality: Javanese Islamic education in a globalizing era. Journal of Arabic and Islamic Studies, 3, 26-48.

Maynard, M. L. (2003). From global to glocal: how Gillette's Sensor Excel accommodates to Japan Sub Title Author Maynard, Michael L. Publisher Institute for Communications Research, Keio University Publication year 2003.

Robertson, R. (1992). Globalization: Social theory and global culture. London: Sage.

Robertson, R. (1995). Glocalization: Time-space and homogeneity-heterogeneity. Global modernities, 25-44.

Straubhaar, J. (1991). Beyond media imperialism: Asymmetrical interdependence and cultural proximity. Critical Studies in Media Communication, 8 (1), 39-59.

Wang, Y. (2007). Globalization enhances cultural identity. Intercultural Communication Studies, 16(1), 83.

Wimmer, R. D., \& Dominick, J. R. (1983). Mass media research: an introduction. Wadsworth series in mass communication.

10 Musisi Lokal yang Pernah Dicekal di Indonesia. (2013). Retrieved from http://www.lihat.co.id/2013/12/10MusisiLokalyangpernahdiCekaldiIndonesi a.html\#axzz3PzBRrXxV 